\title{
LEGAL PROTECTION OF TRADITIONAL DANCE ACCORDING TO INTERNATIONAL LAW
}

\author{
Aplia Eka Dewi \\ International Law Departement, Faculty of Law, Universitas Lampung, Indonesia \\ Email: dewiapliaeka@gmail.com
}

Submitted: March 5, 2019; Reviewed: March 29, 2019; Accepted: April 2, 2019

\begin{tabular}{|c|c|}
\hline Article Info & Abstract \\
\hline $\begin{array}{l}\text { Keywords: } \\
\text { Legal Protection, Traditional Dance, } \\
\text { International Law. } \\
\text { DOI: } \\
\text { 10.25041/lajil.v1i1.2023 }\end{array}$ & $\begin{array}{l}\text { Indonesia is a country that consists of various ethnics } \\
\text { that have a diverse culture with the types and forms of } \\
\text { art. One form of traditional art is a traditional dance that } \\
\text { requires maintenance, preservation, and protection to } \\
\text { be enjoyed by the next generation. Traditional dance is } \\
\text { one of the cultural products that are also prone to } \\
\text { become victims such as claims occur in Reog Dance } \\
\text { and Pendet Dance by neighbouring countries. This } \\
\text { research aims to determine the legal protection of } \\
\text { traditional dance in International Law and the } \\
\text { implementation of the legal protection of traditional } \\
\text { dance in Indonesia. }\end{array}$ \\
\hline
\end{tabular}

\section{A. Introduction}

Indonesia is a country that consists of various ethnics that have a diverse culture with the types and forms of traditional art that are distinctive and representative of their respective regions. One of the traditional forms of art is a traditional dance that requires maintenance, preservation, and protection to be enjoyed by the next generation. ${ }^{1}$

Traditional dance is a dance that has been choreographed a process that has been standard work. Traditional dance has undergone a long cultural process or cultural heritage. This type of dance is based on existing patterns of tradition or customs of the ancestors. The dance is a cultural heritage inherited from the hereditary. ${ }^{2}$ As the times progressed, it caused a more modern lifestyle change. As a result, people prefer a new culture that may be considered more practical than the local culture. Indonesian youth play an important role in the preservation of Indonesian art and culture, as they will become future leaders of the nation where they should have cultural awareness so that Indonesian cultures can be maintained. ${ }^{3}$

The importance of traditional dance among others, namely as a means of communication, and as a means of entertainment, but the existence of conventional dance has experienced many legal problems, among others, has been a lot of claims by other countries on cultural heritage, especially in traditional Indonesian dance. Reog Ponorogo dance from East Java, Pendet dance from Bali, Plate dance from Padang, and Tor Tor Dance from North Sumatra, examples of the four have their own characteristics from their respective areas. The fourth dance has similarity because the four have not been registered in UNESCO (United Nations Educational, Scientific, and Cultural Organization). Still, the four are well known to the world because Malaysia neighbouring country Indonesia ever

\footnotetext{
${ }^{1}$ Harry D. Fauzi dan Yadi Mulyadi, Seni Budaya (Bandung: Yrama Widya, 2016), 93.

2 Rahmida Setiawati, Seni Tari (Jakarta: Departemen Pendidikan Nasional, 2008), 166.

${ }^{3} \mathrm{http} / / / \mathrm{rubik} . o k e z o n e . c o m / \mathrm{read} / 30425 /$ indonesia-dengan-gaya-kebarat-baratannya, Accessed on March 28, 2017 at 16:00 WIB
} 
claimed the dance. ${ }^{4}$ The number of cases a country claims against other state-owned traditional knowledge encourages the emergence of demands for protection of Traditional Knowledge has actually emerged since the signing of the Convention on Biological Diversity (CBD) 1992.

In relation to folklore protection, the IPR system used in Indonesia as an instrument of protection against folklore is the Copyright system. Intellectual Property Rights have two almost identical branches, namely Copyright (Copyright) and Patent (Patent). In the Patent, the object is limited to tangible things (tangible), not to the invisible (intangible). An invention or invention may be patented if the invention contains elements: novelty, inventive steps, and industrially applicable. Whereas in Article 1 (3) of the Copyright Act in detail mentioned various creation that is protected that is created in the field of science, art and literature. ${ }^{5}$

Traditional dance regimes can not be incorporated into the legal regime of copyright and patents, because the copyright regime must find its inventor, whereas, in traditional dance, the creator/invention element can not be known because the traditional dance is communally owned. Meanwhile, when incorporated into the patent regime, traditional dance does not have novelty elements because traditional dance is hereditary from generation to generation.

Based on the above description, then the main issues to be discussed are how to protect the law against traditional dance according to international law and implementation of legal protection against traditional dance in Indonesia. Methods of data collection using normative legal research methods. Furthermore, he selected In the collection of data writing using secondary data is data obtained through literature study. Secondary legal materials are materials that are closely related to primary legal materials and can help and analyze the literature, journals, papers, internet sites, and others that are relevant. The methods used in this research is a normative law research method, with data collection technique through literature study. Then performed data analysis in the form of the qualitative analysis method.

\section{B. Discussion}

Legal protection is an act or attempts to protect the public from arbitrary acts by a ruler who is inconsistent with the rule of law, to bring order and peace to enable humans to enjoy their human dignity. If analyzed from the means of legal protection is divided into two, namely the means of protection of preventive law and repressive law protection facilities. ${ }^{6}$ Satjipto Rahardjo said the legal protection theory is the purpose of law in society to integrate and coordinate the interests of society. ${ }^{7}$ Legal protection against traditional dance referred to in this writing is the legal protection concerning all efforts that can guarantee the existence of legal certainty in the field of traditional dance whether it is a preventive effort or legal protection that is repressive under international law.

Traditional dance is a type of dance that grows and live in a particular society, motivated by customs and beliefs of society, and maintained by the community as a symbol of their expression in the form of choreography (dance movement composition).

The dance life in Indonesia during the Japanese occupation is very alarming. It is because the arts at that time should be presented for the interests of colonizers. The life of dance art during the struggle of Indonesian independence in 1945-1950 is very degenerate. After the year 1950 on the advice of the Government of Indonesia through the Culture Office of RI re-emerged regional dances in Indonesia which then developed rapidly. The motivation of regional dances in the independence period is as a place of association and entertainment. Since 1958 appeared dances in the form of short fragments. These dances are then put together into a form of ballet.

Regional dances are growing and increasing rapidly as the government has sought the excavation,

\footnotetext{
${ }^{4}$ http://liputan6.com/news/read/241888/tari-pendet-tayang-berbilang/, Accessed on June 9, 2016 at 17:00 WIB.

${ }^{5}$ Arif Lutviansori, Hak Cipta dan Perlindungan Folklor Di Indonesia (Yogyakarta: Graha Ilmu, 2010), 7.

https://www.merdeka.com/pendidikan/ini-pendapat-andi-hamzah-dan-simanjuntak-soal-perlindungan-hukum.html, Accessed on April 2, 2017 at 15:00 WIB.

${ }^{7}$ Christopher Kendrick Adam, Joe Arifiando Walpa, and Vina Octavia, "PERTANGGUNGJAWABAN PEMERINTAH REPUBLIK INDONESIA TERHADAP HILANGNYA HAK ATAS TANAH MILIK WARGA MASYARAKAT YANG TERKENA ABRASI DI WILAYAH KABUPATEN BREBES JAWA TENGAH THE REPUBLIC OF INDONESIA GOVERNMENT RESPONSIBILITY OF THE CITIZEN LOSS LAND AFFECTED NY ABRATION IN THE REGION OF THE BREBES REGENCY OF CENTRAL JAVA,” Cepalo 4, no. 2 (2020): 61-68, 62, DOI: 10.25041/cepalo.v4no2.1943.
} 
fostering and preservation of dance by: ${ }^{8}$

1. Establishing karawitan.

2. Hold meetings between dance artists, as well as workshops and discussions on the art of dance.

3. Provide art equipment assistance in these areas.

4. Increasing the activities of dance performances.

5. Hold various dancing competitions.

6. Holding election of art ambassadors from each province.

7. Hold National People's Dance Week.

8. Inventories of extinct, endangered, and emerging dances.

9. Giving awards to the creators of dance and dance studios who excel.

10.Provide scholarships to gifted and outstanding learners.

11. Conduct provincial and national level upgrading.

12.Build art centers, such as Cultural Park in each province.

\section{Legal Protection Against Traditional Dance According to International Law}

\section{a. Convention on Biological Diversity (CBD) in 1992}

The Convention on Biological Diversity (CBD) provides an international guideline for the protection of traditional knowledge through Article 8 (j), as well as two other articles relating to Article 8 (j), namely Article 17 (2) and Article 18 (4). Article 8 (j) governs depending on its national legislation, respecting, protecting and retaining local, indigenous and indigenous knowledge, innovations and practices that reflect traditional, traditional lifestyles, in accordance with the conservation and sustainable use of biodiversity and the promotion of its application more broadly with the consent and involvement of knowledge owners such innovations and practices encourage equitable sharing of benefits resulting from the utilization of such knowledge, innovations and practices. Traditional dance belongs to Article 8 (j), i.e. community practices that reflect traditionalstyle lifestyles.

In addition, Article 17 (2) also explains that it is mandatory to exchange information in exchange of technical, scientific and socioeconomic research results, as well as information on training and survey programs, special knowledge, indigenous and traditional knowledge, and in combination with the technologies described in article 16 (1) which states such exchanges must also involve the repatriation of information. ${ }^{9}$ Article 17 can we underline that is the word original and traditional knowledge. It shows that traditional dance is also included in this article because traditional dance is one of the traditional types of knowledge. Traditional knowledge is knowledge owned by the community for generations. Finally, Article 18 (4) is related to national laws and policies, the parties shall encourage and develop methods of cooperation for the development and use of technology, including original and traditional technologies, in order to achieve the objectives of this convention. To this end, the parties shall also promote cooperation in personnel training and expert exchange.

\section{b. Convention for the Safeguarding of the Intangible Cultural Heritage 2003 (UNESCO Convention 2003)}

The UNESCO Convention 2003 governs the inheritance of non- cultural heritage as a range of practices, representations, expressions, knowledge, skills and instruments of related instruments, objects, artefacts and cultural environments encompassing various communities, groups and, in certain respects, individuals who are recognized as part of cultural heritage they. This inherited cultural heritage passed down from generation to generation, is continually reinvented by communities and groups in response to their environment, their interaction with nature, and its history, and gives them a sense of identity and sustainability, to promote respect for cultural diversity and human creativity.

This UNESCO Convention 2003, the consideration will be given only to non-cultural heritage in harmony with existing international instruments on human rights, as well as the mutual respect of

\footnotetext{
${ }^{8}$ Ibid.

${ }^{9}$ Article 17 (2) Convention on Biologycal Diversity.
} 
inter-communities, groups and individuals, and sustainable development. ${ }^{10}$

Inherited cultural heritage is a cultural heritage that can not be perceived with the eyes and hands, but an inherited cultural heritage (WBTB) can only be sensed with ears and reason. Inside the cultural heritage of no objects contained the noble values of the ancestors that we must preserve. ${ }^{11}$ That intangible cultural heritage, as in Article 2 (2) its form that is: ${ }^{12}$ The intangible cultural heritage, as defined in paragraph 1 above, is the manifested among other things in the following domains:

a) oral traditions and expressions, including the language as a vehicle of the intangible cultural heritage; performing arts;

b) social practices, rituals and festive events;

c) knowledge and practices concerning nature and the universe;

d) traditional craftsmanship."

Traditional dance can be said to go into the explanation of Article 2 (2) that is there is a word of performance art. Performing arts are the activities of art that are displayed such as theatre, dance, music and circus. Prior to the convention previously mentioned above, there are similarities in the explanation that existed in the WIPO Convention on the word performing arts. Because dance is one example of the activities of the performing arts, the author believes that traditional dance into Article 2 (2). UNESCO has several criteria of how this batik can deserve confirmation. There are five basic criteria of how cultural heritage can gain an inaugural definition of intangible cultural heritage, inventory, contribution towards visibility of intangible cultural heritage, safeguarding measures, and community participation. ${ }^{13}$

Essentially, the protection of traditional dance as a non-object cultural heritage should undergo several steps in order to be approved, and copyright recognized specifically: ${ }^{14}$

1) Identification, "Identification: The identity of the intangible cultural heritage that occurs through the elaboration of dynamic territorial inventories."

2) Documentation, "Documentation: The intangible heritage of living heritage. As a matter of fact, it is a matter of steady transformation and change. Therefore, the intangible heritage can not be safeguarded but can be fixed through the production of documents. to understand procedures of trade."

3) Conservation, "Conservation: The purpose of the conservation of the catalogue of systems that allows the continuing implementation of the facts."

4) Dissemination, "Dissemination: The intangible heritage is said to be within the form of the protection of the collective intellectual property. Because of this international community, we must ensure that the culture and culture of their bearers "The transmission of the intangible heritage can be promoted through the maintenance of new kinds of creativity."

5) Promotion, "Promotion: The value of intangible heritage shall be disseminated as much as possible through the organization of events such as fairs, festivals, seminars and workshops, through media, radio, and television."

6) the last steps is UNESCO's as the intangible cultural heritage. ${ }^{15}$

The duty of the state should record or identify what the object's cultural heritage is in the territory of each country. Then, the documentation process as official archives of the state. The third is conservation, conservation is carried out the feasibility of elements that exist in the inheritance category of cultural heritage that should be patented or not. Once the information is clear, it is disseminated, and promoted through mass media, electronics, social media, live viewing, talk shows, or art performances and so on. Once the public knows, the state must register it to the UNESCO Committee for the inauguration of the cultural heritage. ${ }^{16}$

${ }^{10}$ Article 2 UNESCO Convention 2003.

11 Kementerian Pendidikan dan Kebudayaan, Pencatatan Warisan Budaya Takbenda Indonesia, 2012, https://kebudayaan.kemdikbud.go.id/pencatatan- wbtb/, Accessed on September 10, 2017 at 08:00 WIB.

12 Article 12 (2) UNESCO Convention 2003.

${ }^{13}$ Ministry of Culture and Tourism, Commitment of the Department of Culture and Tourism Regarding safeguarding of the Culture of Indonesian Batik (Jakarta: Ministry of Culture and Tourism, 2008), 99.

${ }^{14}$ Emanuel Valentin, "INTANGIBLE SEARCH, SEARCHING THE INTANGIBLE: THE PROJECT E.CH.I. AND THE INVENTARISATION OF INTANGIBLE CULTURAL HERITAG," Academic Journal of Interdisciplinary Studies MCSER Publishing 2, no. 8 (2013): 113-120, 113, DOI: 10.5901/ajis.2013.v2n8p113.

${ }^{15}$ Ibid.

${ }^{16} \mathrm{http} / / /$ www.unesco.org/culture/ich/en/directives, Accessed on September 10, 2017 at 15:30 WIB. 


\section{c. The Convention of the World Intellectual Property Organization (WIPO)}

The Convention of the World Intellectual Property Organization (WIPO) explains that Traditional Knowledge (PT) is knowledge passed down from generation to generation within a community. It is often part of the cultural and spiritual identity of the community. The WIPO program at PT also addresses genetic resources (SDG) and traditional cultural expressions (EBT). Although there is no accepted definition of PT at the international level, it can be said that PT in the general sense includes the content of knowledge itself as well as traditional cultural expressions, including distinctive signs and symbols. ${ }^{17}$

According to the WIPO Convention in Article 2 (8) the "intellectual property" shall include rights relating to literary, artistic and scientific works, performing arts, phonograms and broadcasts. Discovery in all areas of human endeavour, scientific discovery, industrial design, trademark, service mark, and commercial name and designations. Protection against the unhealthy competition, and all other rights resulting from intellectual activity in industry, scientific, literary or artistic fields. ${ }^{18}$

To reach this objective, WIPO, similarly to performing the administrative obligations of trade Unions, undertakes a number of actions including the first of its normative actions, concerning the establishment of norms and standards for the protection and enforcement of intellectual property rights through the realization of international treaties. Second, program actions concerning legal and technical aid to countries within the field of intellectual assets. Third, the international category and standardization actions, concerning cooperation between the industrial property office regarding patent documentation, trademark, and industrial design; and the last is the registration and archiving actions, concerning services related to international applications for discovery and the registration of brands and industrial designs. ${ }^{19}$

\section{d. Agreement Trade-Related Aspects of Intellectual Property Right (TRIPs)}

Agreement Trade-Related Aspects of Intellectual Property Rights (TRIPs) does not explain the notion of traditional knowledge, but in the TRIPs described the intellectual property rights. Intellectual property rights are rights granted to others based on the creations of their minds. They usually give the creator an exclusive right to the use of his creations for a certain period of time. The rights of literary and art writers (such as books and other writings, musical compositions, paintings, sculptures, computer programs and films) are protected by copyright, for a minimum period of 50 years after the author's death. Copyright and related rights are the rights of players (e.g. actors, singers and musicians), producers of sound recordings (voice recordings) and broadcasting organizations. The main social purpose of copyright and related rights protection is to encourage and appreciate creative work. $^{20}$

Relevant provisions may be found in Article 2 (2) of the TRIPS Agreement, which relates to the Berne Convention, which contains: ${ }^{21}$

"Nothing in Part I of IVI of the Convention, the Berne Convention, the Rome Convention and the Treaty on Intellectual Property in Respect of Integrated Circuits".

Article 9. (1) which reads:

"Members will comply with Articles 1 through 21 of the Berne Convention (1971) and the Appendix thereto. However, there is no such thing as a reference to the convention on the Rights of the Constitution."

Article 2 (1) of the Berne Convention, which reads:

"The expression" literary and artistic works "shall include every production in the literary, scientific and artistic domain, whatever may be the mode or form of its expressions, such as books, pamphlets and other writings; lectures, addresses, sermons and other works of the same nature;

\footnotetext{
${ }^{17} \mathrm{http} / / / \mathrm{www} . w i p o . i n t / \mathrm{tk} / \mathrm{en} /$, Accessed on September 5, 2017 at 21:17 WIB.

${ }^{18}$ Article 2 (8) WIPO Convention.

${ }^{19} \mathrm{http} / / /$ www.wipo.int/treaties/en/convention/summary_wipo_convention.html, Accessed on October 2, 2017 at 21:00 WIB.

${ }^{20} \mathrm{https} / / /$ www.wto.org/english/tratop_e/TRIPs_e/intel1_e.htm, Accessed on September 11, 2017 at 20:00 WIB.

${ }^{21} \mathrm{https} / / /$ www.wto.org/english/docs_e/legal_e/27-TRIPs_03_e.htm, Accessed on October 2, 2017 at 22:00 WIB.
} 
dramatic or dramaticomusical works; choreographic works and entertainments in dumb show; musical compositions with or without words; cinematographic works to which are assimilated works expressed by a process analogous to cinematography; works of drawing, painting, architecture, sculpture, engraving and lithography; photographic works to which is assumed works exposed by a process analogous to photography; works of applied art; illustrations, maps, plans, sketches and three-dimensional works relative to geography, topography, architecture or science."

Article 2 (1) can be known as the works of literature and artwork described their choreographic works in it. Choreographic works (choreography) shows that dance is also included in the explanation of the article. The choreography previously discussed in WIPO, means the art of creating and transforming dance. Traditional dance must have choreography because dance is formed from choreography created by a dancer or often referred to as choreographer.

\section{Implementation of Legal Protection against Traditional Dance in Indonesia}

Indonesia entered as a member of the WTO (World Trade Organization) in 1994 by ratifying the results of the Uruguay Round Agreement Establishing the World Organization (Agreement Establishing World Trade Organization). One of the most important parts of WTO approval is the Agreement on Trade-Related Aspects of Intellectual Property Rights Including Trade-In Counterfeit Goods (TRIPs). In line with TRIPs, the Indonesian government has also ratified the International Conventions in IPR, namely:

a. Paris Convention for the protection of the Industrial Property and Convention Establishing the World Intellectual Property Organization, with Presidential Decree No. 15 of 1997 concerning the amendment of Presidential Decree no. 24 of 1979;

b. Patent Cooperation Treaty (PCT) and Regulation under the PTC, with Presidential Decree NO. 16 of 1997

c. Trademark Law Treaty (TML) with Presidential Decree. 17 of 1997;

d. Bern Convention for the Protection of Literary and Artistic Works with Presidential Decree No. 18 of 1997 ;

e. WIPO copyrights treaty (WCT) with Presidential Decree no. 19 of 1997;

Following the UNESCO Convention 2003, the Presidential Regulation concerning the ratification or convention for the safeguarding of the intangible cultural heritage of 2003 was enacted in Jakarta on July 5, 2007, By the Minister of Justice and Human Rights of the Republic of Indonesia at that time that is Andi Mattalatta. Through Presidential Regulation No. 78 of 2007, this Presidential Regulation shall come into force on the date of the stipulation. ${ }^{22}$

Indonesia's intangible cultural heritage has been regulated in the Minister of Education and Culture of the Republic of Indonesia Number 106 Year 2013 About Indonesia's Unspecified Cultural Heritage, Enacted in Jakarta on December 16, 2013. In Article 1 (2) which reads: ${ }^{23}$

"Indonesia's cultural heritage is the result of practice, manifestation, expression of knowledge and skills, related to the cultural sphere, passed from generation to generation continuously through conservation and/or recreation and is the result of the culture in the form of intangible culture after going through the process of establishing Culture No Object".

Traditional dance is included in the category of cultural heritage no object Indonesia is contained in Article 3, which consists of:

a. Traditions and oral expressions;

b. Performing arts;

c. People's customs, rites, and celebrations;

d. Knowledge and behavioural habits regarding nature and the universe; and/or

e. Skills and finesse of traditional crafts.

The determination of the object's cultural heritage has been held on October 17, 2014, at the National Museum of Jakarta. This determination is a manifestation of the commitment of Indonesia which has ratified Convention on Protection of the Intangible Cultural Heritage (Convention for the

\footnotetext{
${ }^{22}$ President Regulation No. 78/2007.

${ }^{23}$ http://jdih.kemdikbud.go.id/asbodoku/media/peruu/permen_tahun2013_nomor106.pdf, Accessed on December 28, 2017 at 15:00 WIB.
} 
Safeguarding of the Intangible Cultural Heritage) in 2003..$^{24}$

Currently, the Department of Culture and Tourism has made various efforts to protect the utilization of cultural heritage, among others:

a. Requests to local governments to carry out inventories in accordance with Traditional Knowledge and Traditional Cultural Expressions (since 2003) are based on Circular Letter of the Minister of Culture and Tourism Number: SE.01/HK.501/MPK/200.

b. Intellectual Property Inventory of Traditional Knowledge (PT) and Traditional Cultural Expression (EBT) such as architecture, weaving in some parts of Indonesia.

c. Preparation of the document "Overview of Intellectual Property Protection Efforts on Traditional Knowledge and Traditional Cultural Expressions".

d. Preparation and issuance of Minister of Culture and Regulation concerning Guidelines and Criteria of Cultural Heritage Protection of Intangible. The Ministry of Culture and Tourism has also signed a partnership with the Ministry of Law and Human Rights to protect, develop and utilize the intellectual property of traditional cultural heritage expressions of the nation.

The government, in this case, has reminded the governors, regents and mayors throughout Indonesia to actively conduct an inventory of local cultural works, including traditional dance. Once inventoried, then the work of regional culture is registered to the Department of Law and Human Rights to get intellectual property rights (IPR). Then the follow-up to the international realm of registration to UNESCO. ${ }^{25}$

\section{Conclusion}

Legal protection of traditional dance according to international law is regulated in 4 conventions, among which the first is Convention on Biological Diversity in 1992 through Article 8 (j), Article 17 (2) and Article 18 (4). Then the second is the UNESCO Convention 2003 on The Safeguarding Of The Intangible Cultural Heritage in chapter 2 (2). Furthermore, the Convention of the World Intellectual Property Organization (WIPO) in Article 2 (8). The last is TRIPs Agreement Article 2 (2), and Article 9 (1) describes the protection of literary works and artwork through the Berne Convention.

Formally, Indonesia has provisions, among others: Law Number 28 Year 2014 on Copyright, ratified UNESCO Convention 2003 with Presidential Regulation No.78 of 2007, the Regulation of the Minister of Education and Culture of the Republic of Indonesia Number 106 Year 2013 About Inheritance intangible Culture Indonesia, ratified the Berne Convention with Presidential Decree No. 18 of 1997, and WIPO copyright treaty (WCT) with Presidential Decree No. 19 of 1997. In materially, Indonesia's efforts to protect traditional dance one of them by holding an annual event that is Indonesia Dance at Galeri Indonesia Kaya. Then the Ministry of Culture and Tourism has made various efforts to protect the utilization of cultural heritage, among others, requests to local governments undertake inventory, inventory of intellectual property, Traditional Knowledge (PT) and Traditional Cultural Expression (EBT), compilation of documents, preparation and publishing of Menbudpar on Guidelines and Criteria of Cultural Heritage Protection of intangible.

\section{Suggestion}

In the four conventions described above, in general, does not explain in detail how the process of the legal protection of Traditional Dance, only at the UNESCO Convention 2003 can be found stages of how the process of protection of traditional dance into the non-object cultural heritage. It is also advisable that other conventions can also provide clearer protection of traditional dance to the stage of a stipulation that will be recognized in the world as was the case with the UNESCO Convention 2003.

The public should be able to try, maintain, preserve, and mechanize the government to be proactive in preserving traditional dance in Indonesia. The author hopes dance communities that always hold Indonesia Dance every year is not only held in downtown Jakarta alone but in all regions in Indonesia

\footnotetext{
${ }^{24}$ http://travel.kompas.com/read/2014/10/24/175400427/memelihara.warisan.budaya.tak.bend/, Accessed on September 11, 2017 at 10:00 WIB.

${ }^{25}$ Ibid.
} 
A. Journal

\section{References}

Adam, Christopher Kendrick., et.al. "PERTANGGUNGJAWABAN PEMERINTAH REPUBLIK INDONESIA TERHADAP HILANGNYA HAK ATAS TANAH MILIK WARGA MASYARAKAT YANG TERKENA ABRASI DI WILAYAH KABUPATEN BREBES JAWA TENGAH THE REPUBLIC OF INDONESIA GOVERNMENT RESPONSIBILITY OF THE CITIZEN LOSS LAND AFFECTED NY ABRATION IN THE REGION OF THE BREBES REGENCY OF CENTRAL JAVA," Cepalo 4, no. 2, 2020: 61-68, DOI: 10.25041/cepalo.v4no2.1943.

Valentin, Emanuel. "INTANGIBLE SEARCH, SEARCHING THE INTANGIBLE: THE PROJECT E.CH.I. AND THE INVENTARISATION OF INTANGIBLE CULTURAL HERITAGE", Academic Journal of Interdisciplinary Studies MCSER Publishing 2, no. 8, 2013: 113-120, DOI: 10.5901/ajis.2013.v2n8p113.

\section{B. Book}

Lutviansori, Arif. Hak Cipta Dan Perlindungan Folklor Di Indonesia. Yogyakarta: Graha Ilmu, 2010.

Fauzi, Harry D. dan Yadi Mulyadi. Seni Budaya. Bandung: Yrama Widya, 2016.

\section{Regulation}

Convention on Biological Diversity.

Heritage 2003 (UNESCO Convention, 2003).

President Regulation No 78 of 2007 Regarding Ratification of the 2003 UNESCO Convention.

Setiawati, Rahmida, dkk. Seni Tari. Departemen Pendidikan Nasional, 2008.

Unesco Convention For The Safeguarding of the Intangible Cultural.

\section{Internet}

http://jdih.kemdikbud.go.id/asbodoku/media/peruu/permen_tahun2013_nomor106.pdf, Accessed on December 28, 2017.

http://liputan6.com/news/read/241888/tari-pendet-tayang- berbilang/, Accessed on June 9, 2016.

http://rubik.okezone.com/read/30425/indonesia-dengan-gaya- kebarat-baratannya/, Accessed on March 28, 2017.

http://travel.kompas.com/read/2014/10/24/175400427/memelihara.warisan.budaya.tak.benda./,

Accessed on September 11, 2017.

http://www.unesco.org/culture/ich/en/directives http://www.wipo.int/tk/en/, Accessed on September 10, 2017.

http://www.wipo.int/treaties/en/convention/summary_wipo_convention.html, Accessed on October 2, 2017.

https://www.wto.org/english/docs_e/legal_e/27-TRIPs_03_e.htm, Accessed on September 11, 2017. https://www.wto.org/english/tratop_e/TRIPs_e/intel1_e.htm, Accessed on September 11, 2017. 